\title{
PENGGUNAAN KARYA CIPTA MUSIK DAN LAGU TANPA IZIN DAN AKIBAT HUKUMNYA
}

\author{
Hulman Panjaitan ${ }^{1}$
}

\begin{abstract}
Copyrightis avery important part of Intellectual Property Rights, especially inthe field of creative works of musicandsong; the infringement is very alarming and serious in Indonesia.Copyright is an exclusive right or special right which means that other people cannot take advantage of economic rights of creators on his creations without prior approval of the legal creators or copyright holders.The consequence is in each use of music for commercial businesses and or interests related to business activities/commercial purposessuch ascafes, hotels, restaurant sands of orthmust firstask approval from thecreators or copy right holders on the use of the music creation.
\end{abstract}

\section{Kata Kunci: Pengggunaan Karya Cipta Tanpa Izin}

\section{PENDAHULUAN}

Salah satu bagian penting dari Hak Kekayaan Intelektual $^{2}$ adalah hak cipta, yang menurut undangUndang RI No. 28 Tahun 2014 tentang Hak Cipta (selanjutnya disebut UUHC) adalah hak eksklusif pencipta yang timbul secara otomatis berdasarkan prinsip deklaratif setelah suatu ciptaan diwujudkan dalam bentuk nyata tanpa mengurangi pembatasan sesuai dengan ketentuan peraturan perundang-undangan $^{3}$. Hak eksklusif dimaksud adalah hak yang semata-mata diperuntukkan bagi pemegangnya, sehingga tidak ada pihak lain yang boleh memanfaatkan hak tersebut tanpa izin pemegang hak ciptanya.

\footnotetext{
${ }^{1}$ Dosen Tetap Fakultas Hukum UKI.

${ }^{2}$ Dalam kepustakaan hukum Indonesia terdapat istilah yang dipergunakan untuk menyebut Hak Kekayaan Intelektual, yaitu Hak Milik Intelektual (digunakan oleh Muh. Djumhana), Hak Atas Kekayaan Intelektual (HAKI) (digunakan oleh Suyud Margono) dan Hak Kekayaan Intelektual sesuai Keputusan Menteri Hukum dan Perundang-undangan RI No. M.03.PR.07.10 tahun 2000 dan terakhir dilingkungan Kementerian Hukum dan HAM RI dipergunakan istilah Kekayaan Intelektual (KI).

${ }^{3}$ Pasal 1 angka (1) Undang Undang Republik Indonesia Nomor 28 Tahun 2014 tentang Hak Cipta. Bandingkan dengan rumusan hak cipta menurut Undang Undang No. 19 Tahun 2002 tentang Hak Cipta, yaitu suatu hak eksklusif bagi pencipta atau penerima hak untuk mengumumkan atau memperbanyak ciptaannya yang timbul secara otomatis setelah suatu ciptaan dilahirkan atau memberi izin untuk itu dengan tidak mengurangi pembatasan-pembatasan menurut peraturan perundang-undangan yang berlaku.
}

Dari sekian banyak ciptaan yang dilindungi menurut undang-undang ${ }^{4}$, pada kesempatan ini, penulis akan lebih mengkhususkan pembahasan pada hak cipta musik dan lagu, mengingat maraknya pelanggaran yang terjadi atas hak cipta ini, baik pelanggaran dalam hal mechanical right (hak untuk mengumumkan) maupun dalam hal performing right (hak untuk memperbanyak).

Banyaknya pelanggaran hak cipta atas karya cip- ta musik dan lagu di bidang perbanyakan atau penggandaan tanpa izin, secara kasat mata dapat dilihat di berbagai pusat-pusat perbelanjaan, baik tradisional maupun modern, seolah tidak pernah terjamah dan terkesan dibiarkan, apalagi pembajaknya. Ada beberapa

\footnotetext{
${ }^{4}$ Menurut Pasal 40 UUHC, ciptaan yang dilindungi adalah : a). buku, pamphlet, perwajahan karya tulis yang diterbitkan dan semua hasil karya tulis lainnya; b). ceramah, kuliah, pidato dan ciptaan sejenis lainnya; c). alat peraga yang dibuat untuk kepentingan pendidi- kan dan ilmu pengetahuan; d). lagu dan/atau music dengan atau tanpa teks; e). drama, drama musical, tari, koreografi, pewayan- gan dan pantomin; f). karya seni rupa dalam segala ebntuk seperti lukisan, gambar, ukiran, kaligrafi, seni pahat, patung atau kolase; g). karya seni terapan; h). karya arsitektur; i). peta; j). karya seni batik atau seni motif lain; k). karya fotografi; 1). potert; m). karya sinematografi; $\mathrm{n}$ ). terjemahan, tafsir, saduran, bunga rampai, ba- sis data, adaptasi, aransemen, modifikasi dan karya lain dari hasil transformasi; 0). Terjemahan, adaptasi, aransemen, transformasi atau modifikasi ekspresi budaya tradisional; p). kompilasi ciptaan atau data, baik dalam format yang dapat dibaca dengan program computer maupun media lainnya; q). kompilasi ekspresi budaya tradisional selama kompilasi tersebut merupakan karya yang asli; r). permaninan video, dan; s). program computer.
} 
orang yang dihadapkan ke meja hijau, tetapi hanyalah mereka yang menjual barang bajakan, sedangkan pembajak (pabrikan) tidak pernah tersentuh.

Melihat maraknya pelanggaran hak cipta, Hulman Panjaitan ${ }^{5}$ pernah mengemukakan bahwa khusus untuk hak cipta lagu atau musik dapat dikatakan perlindungannya menjadi masalah serius di Indonesia. Bahkan Indonesia pernah dikecam dunia internasional karena lemahnya perlindungan hukum terhadap hak cipta lagu atau musik tersebut. Sesuai laporan kantor perwakilan perdagangan Amerika Serikat (USTR atau United States Trade Representative) sebelum tahun 2000, Indonesia merupakan satu-satunya negara ASEAN yang masuk dalam kategori Priority Watch List ${ }^{6}$. Tahun 2000 atas rekomendasi IIPA (Internaional Intellectual Property Aliance), USTR menyetujui Indonesia masuk peringkat Watch List ${ }^{7}$. Namun demikian, kembali pada tahun 2001 dan tahun 2002, IIPA merekomendasikan kepada USTR dan WIPO untuk tetap memasukkan Indonesia dalam peringkat Priority Watch List yang kemudian disetujui dengan alasan bahwa tingkat pembajakan di pasar Indonesia begitu luas terhadap hak cipta dan barang-barang merek merupakan yang tertinggi di dunia.

Harian Bisnis Indonesia, 2 September 2010 pernah merilis bahwa berdasarkan survey yang dilakukan oleh Political and Economic Risk Consultancy (PERC), Indonesia adalah pelanggar hak kekayaan intelektual terburuk di Asia. Hasil ini diperoleh berdasarkan wawancara dengan 1.285 manajer ekspatriat dalam rentang waktu Juni sampai pertengahan Agustus 2010. Hasil survey itu menenpatkan Indonesia pada angka 8,5 dari angka maksimum 10 yang berarti menduduki posisi teratas diantara 1 negara lain di kawasan Asia. Di bawah Indonesia ada Vietnam $(8,4)$, China $(7,9)$, Filipina $(6,8)$, India $(6,5)$, Thailand $(6,1)$ dan Malaysia $(5,8)$. Singapura adalah Negara terbaik di Asia dalam hal penghormatan terha-

\footnotetext{
${ }^{5}$ Hulman Panjaitan, Lisensi Pengumuman Musik/Lagu dan Aspek Hukumnya, dalam Majalah POTRET, Nopember-Desember 2009, halaman 61. Lihat juga artikel "Pemahaman Hak Cipta Rendah, Pembajakan Lagu Marak" oleh Hulman Panjaitan dalam harian Suara Pembaruan, 3 Agustus 2009.

${ }^{6}$ Priority Watch List adalah suatu peringkat dimana pelangga- ran atas hak kekayaan intelektual (HKI) tergolong berat sehingga Amerika Serikat merasa perlu memprioritaskan pengawasannya terhadap pelanggaran HKI di suatu negara mitra dagangnya.

${ }^{7}$ Watch List adalah suatu peringkat dimana negara yang bersangkutan cukup diawasi karena tingkat pelanggaran HKI terutama hak
}

dap Intellectual Property Right (IPR)-Hak Kekayaan Intelektual ${ }^{8}$.

Khusus di bidang hak cipta atas karya cipta mu- sik dan lagu, persoalan yang dihadapi para pencipta sangat konvensional, yakni sikap dan pandangan para pengusaha hiburan (user) yang menganggap bahwa memutar atau menyanyikan lagu-lagu orang lain tidak perlu meminta izin kepada pencipta dan atau pemegang hak ciptanya dan tidak perlu membayar royalty. Mereka beranggapan, kalau telah membeli kaset, CD atau VCD, mereka sudah bebas menggunakan- nya untuk kegiatan hiburan tanpa terikat lagi kepada pencipta dan atau pemegang hak cipta, padahal dalam aktivitas mereka, para "pengusaha" tersebut menjual hiburan dengan memanfaatkan dan tidak jarang dari karya cipta orang lain. Hal ini disebabkan kurangnya pemahaman atas ketentuan-ketentuan yang terdapat di undang-undang dan kurangnya kesadaran terhadap penghargaan karya cipta orang lain dan karenanya perlu ditumbuhkan, termasuk penegakan hukum terhadap pelanggaran hak cipta lagu dan musik.

Hal yang sama terjadi pada kegiatan pemutaran dan atau penggunaan musik melalui pesawat televisi yang umumnya digunakan pada usaha/kamar hotel, kereta api, pesawat udara, bandara dan tempat-tempat lainnya. Para pengusaha beranggapan bahwa mereka tidak perlu mendapat izin dari pencipta dan atau pemegang hak ciptanya dan tidak perlu membayar royalty lagi karena hal tersebut adalah merupakan tanggung jawab lembaga penyiaran.

Kenyataan yang sesungguhnya adalah bahwa apa yang diberikan oleh pemegang hak cipta kepada lembaga penyiaran adalah izin atau lisensi pengumuman musik dan lagu, dan karenanya, lembaga penyiaran tidak berwenang untuk mengalihkan dan atau memberikan izin/lisensi pengumuman musik kepada siapapun, sehingga dengan demikian para pengusaha yang bersangkutan sesuai dengan undang-undang hak cipta tetap harus minta izin kepada pencipta dan atau pemegang hak cipta dan melakukan pembayaran royalty sebagai kewajiban hukumnya.

Dilatarbelakangi maraknya pelanggaran terhadap hak cipta musik, baik bidang performing right maupun mechanical right sebagaimana diuraikan di atas, dirasakan perlu memberikan pemahaman kepada masyarakat, khususnya para user atau para pelaku

\footnotetext{
${ }^{8}$ Harian Bisnis Indonesia, Kamis, 2 September 2010, hal. 10.
} 
usaha hiburan yang telah banyak mengambil manfaat ekonomi dari karya cipta musik dan lagu orang lain yang dipergunakan dalam kegiatan usahanya tanpa izin dari pencipta atau pemegang hak ciptanya yang sah.

\section{PERMASALAHAN}

1. Bagaimanakah konsekuensi hukum dari hak cipta sebagai suatu hak yang eksklusif?

2. Bagaimana akibat hukum dari penggunaan karya cipta music dan lagu tanpa seizin dari pencipta atau pemegang hak cipta?

\section{Tujuan Penulisan}

1. Untuk mengetahui konsekuensi hukum dari hak cipta sebagai suatu hak yang eksklusif.

2. Untuk mengetahui akibat hukum dari penggunaan karya cipta musik dan lagu tanpa seizing dari pencipta atau pemegang hak cipta.

\section{HAK CIPTA ATAS KARYA CIPTA MUSIK DAN LAGU}

Di dalam UUHC tidak terdapat pengaturan khusus tentang pengertian hak cipta lagu dan/atau musik. Ia hanya merupakan salah satu karya yang dilindungi melalui UUHC sebagaimana juga karya-karya lain yang dicantumkan dalam Pasal 40 UUHC. Tepatnya diatur dalam Pasal 40 ayat (1) sub (d), yaitu ciptaan lagu atau musik dengan atau tanpa teks. Oleh karena itu, terhadap lagu dan/atau musik berlaku semua aturan umum yang juga berlaku untuk karya lainnya, kecuali disebutkan secara khusus tidak berlaku.

Dalam Penjelasan Pasal 40 ayat (1) UUHC ini khususnya sub (d) ditegaskan bahwa karya lagu atau musik dalam pengertian undang-undang diartikan sebagai satu kesatuan karya cipta yang bersifat utuh. Pengertian utuh dimaksudkan bahwa lagu atau musik tersebut merupakan suatu kesatuan karya cipta.

Terkait dengan pengaturan hak cipta lagu dan musik dalam undang-undang sebagaimana diuraikan di atas, Otto Hasibuan ${ }^{9}$ ) mengemukakan keberatannya bahwa ketentuan yang menyamakan lagu dan musik dalam pasal tersebut bukanlah tidak menimbulkan masalah, tetapi jika disimak lebih jauh akan

\footnotetext{
${ }^{9}$ Otto Hasibuan, Hak Cipta Di Indonesia, Tinjauan Khusus Hak Cipta Lagu, Neightboring Rights dan Collecting Society, Bandung: PT. Alumni, 2008, hal. 146.
}

menciptakan kerancuan karena:

1. Pertama, adakalanya sebuah lagu menggunakan lirik yang berasal dari sebuah puisi, sementara puisi termasuk ciptaan karya sastra yang mendapat perlindungn tersendiri, baik dalam Konvensi Bern maupun UUHC.

2. Kedua, arransemen musik (arrangement of music) adalah karya turunan (derivative work) yang menurut Konvensi Bern dilindungi sebagai ciptaan yang berdiri sendiri, setara dengan karya terjemahan (translation). Anehnya, dalam UUHC diakui bahwa karya terjemahan merupakan ciptaan yang dilindungi secara tersendiri, tetapi arransemen musik tidak.

3. Ketiga, dalam UUHC diakui bahwa pemusikmerupakan salah satu unsur dari pelaku yang merupakan pemegang hak terkait. Akan tetapi, tidak ada penjelasan apakah pemusik yang disebut sebagai pelaku itu adalah peñata musik (arranger) atau pemain musik atau keduanya.

Secara etimologi, lagu atau musik pada dasarnya mempunyai perbedaan arti. Lagu adalah suatu kesatuan musik yang terdiri atas susunan pelbagai nada yang berurutan. Setiap lagu ditentukan oleh panjangpendek dan tinggi rendahnya nada-nada tersebut, di samping itu irama juga memberi corak tertentu kepada suatu lagu. Bintang Sanusi ${ }^{10)}$ mengemukakan bahwa dalam istilah populer, musik diartikan sebagai cetusan ekspresi isi hati yang dikeluarkan secara teratur dalam bentuk bahasa bunyi (lagu). Apabila cetusan ekspressi isi hati dikeluarkan melalui mulut disebut vokal, dan apabila dikeluarkan melalui alat musik disebut instrumental.

Di dalam praktik musik vokal dan instrumental dapat dibunyikan secara terpisah, dapat pula dibunyikan bersama-sama, misalnya penyanyi dengan memakai iringan gitar atau band musik dapat dibunyikan sendirian (solo) atau beberapa orang bersama-sama (koor). Di dalam perkembangannya musik dapat dibedakan ke dalam musik tradisional sebagai tarling, musik kolintang dan musik non tradisional misalnya pop, jazz dan lain-lain.

Menurut Kamus Besar Bahasa Indnesia ${ }^{11}$ ), yang dimaksud dengan lagu adalah: 1). Ragam suara yang

\footnotetext{
${ }^{10}$ Bintang Sanusi, Hukum Hak Cipta, Bandung : PT. Citra Aditya Bhakti, 1998, hal. 96.

${ }^{11}$ Departemen Pendidikan Nasional, Kamus Besar Bahasa Indonesia, Jakarta : Balai Pustaka, 2005, hal. 624.
} 
berirama (dalam bercakap, bernyayi, membaca, dan sebagainya); 2). Nyanyian; 3). Ragam nyanyi (musik, gamelan dan sebagainya)-keroncong asli; 4). Tingkah laku; cara; lagak. Sedangkan musik adalah: 1). Ilmu atau seni menyusun nada atau suara dalam urutan kombinasi dan hubungan temporal untuk menghasilkan komposisi (suara) yang mempunyai kesatuan dan kesinambungan; 2). Nada atau suara yang disusun demikian rupa sehingga mengandung irama, lagu dan keharmonisan (terutama yang menggunakan alat-alat yang dapat menghasilkan bunyibunyian itu) ${ }^{12}$ ).

Menurut Ensiklopedia Indonesia ${ }^{13}$ ), sebuah lagu terdiri dari beberapa unsur, yaitu melodi, lirik, arransemen dan notasi. Melodi adalah suatu deretan nada yang karena kekhususan dalam penyusunan menurut jarak dan tinggi nada, memperoleh suatu watak tersendiri dan menurut kaidah musik yang berlaku membulat jadi suatu kesatuan organik. Lirik adalah syair atau kata-kata yang disuarakan mengiringi melodi. Harsono Adisumarto ${ }^{14}$ ) mengemukakan bahwa lirik adalah kata-kata atau syair untuk dinyanyikan. Dapat juga dirumuskan bahwa lirik adalah susunan kata sebuah nyanyian, teks atau kata-kata lagu. Arransemen adalah peralatan terhadap melodi. Selanjutnya notasi adalah penulisan melodi dalam bentuk not balok atau not angka.

Sedangkan musik adalah seni menyusun suara atau bunyi. Musik tidak bisa dibatasi dengan seni menyusun bunyi atau suara indah semata-mata. Sebagaimana dikutip Rooseno Hardjowidigdo ${ }^{15}$ ), pada dasarnya semua musik berisi elemen-elemen dasar tertentu, yaitu rhythm, melody, harmony dan form. Rhythm meliputi jangka waktu atau panjang suara musik. Isi dari rhythm adalah getaran atau gerakan irama yang tetap (steady beat), ukuran (meter), dan tekanan (accent). Jika gerakan irama (beat) digabung dalam satu kumpulan dua, tiga atau lebih dalam satu ukuran, hasilnya disebut meter. Ukuran dari ketukan kuat atau lemahnya tekanan diulang terus menerus sebagai irama satu, dua, tiga,... satu, dua, tiga.

\footnotetext{
${ }^{12} \mathrm{Ibid}$, hal. 766 .

${ }^{13}$ Ensiklopedia Indonesia, buku 4, Jakarta : PT. Ichtiar Baru-van Hove, tanpa tahun, hal. 1941.

${ }^{14}$ Adisumarto Hadisumarno, Hak Milik Intelektual Khususnya Hak Cipta, Jakarta : Akademika Pressindo, 1990, hal.14.

${ }^{15}$ Rooseno Hardjowidigdo, Perjanjian Lisensi Hak Cipta Musik Dalam Pembuatan Rekaman, Jakarta : Perum Percetakan Negara RI, hal. 75.
}

Melodi, terdiri dari pola titi nada (pitch) atau tinggi rendahnya nada (tone). Beberapa macam musik atau tipe musik hampir kesemuanya terdiri dari melody. Tipe yang lain mungkin juga berdasarkan pada suatu tema (motif) atau pengulangan rangkaian nadanada (notes). Jika melodi dalam komposisi yang panjang diulang pada bentuk yang berbeda, nada dasar ini disebut tema atau pokok. Harmony, tertuju pada bentuk bunyi paduan nada (chord) yang dimainkan bersama dan diperoleh dari ukuran dasar musik. Hal itu juga meliputi perintah rangkaian bentuk bunyi paduan nada yang menyertai melodi. Awal melodi adalah lagu (tone) nada dasar yang sama (monotone) atau hampir dengan tiada suatu selingan (variation), tetapi perubahan harmoni ditambah warna, getaran dan pelepasan gubahan (composition).

Sedangkan form, merupakan hasil dari rhythm, melody dan harmony yang disetel atau dipasang (to put together). Musik yang bagus memiliki kesatuan untuk memuaskan telinga pendengar dan selingan untuk memelihara minat. Bahkan sebuah aransemen dari suatu musik jika dengan mengikuti irama sebuah musik tertentu dapat dipakai sebagai terapi penyembuhan penderita narkoba.

Sekalipun pengertian lagu dan musik berbeda, tetapi kepustakaan hak cipta tampaknya tidak membedakannya. Di dalam kepustakaan hukum internasional, istilah yang lazim digunakan untuk menyebutkan lagu atau musik adalah musical work. Konvensi Bern menyebutkan salah satu work yang dilindungi adalah komposisi musik (music compositions) dengan atau tanpa kata-kata (with or without words). Tidak ada uraian yang tegas dalam Konvensi Bern tentang apa sesungguhnya musical work itu. Namun, dari ketentuan yang ada dapat disimpulkan bahwa ada dua jenis ciptaan musik yang dilindungi hak cipta, yaitu musik dengan kata-kata dan musik tanpa kata-kata. Musik dengan kata-kata berarti adalah lagu yang unsurnya terdiri dari melodi, lirik arransemen, dan notasi, sedangkan musik tanpa kata-kata adalah musik yang hanya terdiri dari unsur melodi, arransemen dan notasi.

Dalam kaitannya dengan perlindungan suatu karya cipta lagu dan/atau musik, yang sering dipersoalkan adalah, lagu atau musik yang bagaimanakah yang dilindungi sebagai suatu ciptaan menurut undang-undang. Permasalahan ini menjadi penting karena bisa saja banyak orang menyanyikan lagu yang 
melodi dan liriknya sembarangan atau dapat memainkan alat musik yang menghasilkan nada-nada yang tidak jelas. Sebagaimana diuraikan sebelumnya bahwa hak cipta hanya melindungi ide yang sudah berwujud atau memiliki bentuk ( psycal form) dan asli (original). Perlindungan hak cipta tidak pernah diberikan pada ide atau gagasan karena karya cipta harus memiliki bentuk yang khas, bersifat pribadi dan menunjukkan keaslian sebagai ciptaan yang lahir berdasarkan kemampuan, kreativitas dan keahlian sehingga ciptaan itu dapat dibaca dan didengar. Sehingga dengan demikian, lagu yang dinyanyikan dengan melodi dan lirik yang sembarangan bukanlah suatu ciptaan yang dilindungi menurut undang-undang.

\section{HAK CIPTA SEBAGAI HAK EKSKLUSIF}

Sebagaimana diuraikan diatas, bahwa sesuai dengan UU RI No. 28 tahun 2014, hak cipta (musik) adalah merupakan hak yang eksklusif dalam arti hak yang semata-mata hanya diperuntukkan bagi pencipta dan atau pemegang hak ciptanya untuk mengumumkan dan atau memperbanyak ciptaannya dan karenanya tidak ada pihak lain yang dapat memanfaatkannya tanpa izin terlebih dahulu dari pencipta dan atau dari pemegang hak ciptanya.

Hendra Tanu Atmadja ${ }^{16)}$ mengemukakan bahwa hak cipta terdiri atas sekumpulan hak eksklusif bagi pemilik hak cipta untuk mengizinkan pihak lain menggunakan karya ciptanya, sebaliknya juga dapat melarang pihak lain untuk menggunakan karya ciptanya tersebut. Hak-hak eksklusif itu adalah esensi dari kepemilikan hak cipta.

Dalam kaitan ini, Suyud Margono ${ }^{17)}$ mengemukakan bahwa undang-undang hak cipta memberikan pengertian bahwa hak cipta sebagai hak khusus, hal ini berarti pemahaman undang-undang berpangkal pada melekatnya sifat khusus kepada pencipta atau pemilik hak tersebut dikaitkan dengan pemikiran tentang perlunya pengakuan dan penghormatan terhadap jerih payah pencipta atas segala daya, upaya dan pengorbanan telah terlahir suatu karya atau suatu ciptaan. Lebih lanjut beliau mengemukakan bahwa dalam perspektif ekonomi apabila manfaat yang di-

\footnotetext{
${ }^{16}$ Hendra Tanu Atmadja, Hak Cipta Musik Atau Lagu, Jakarta : Fakultas Hukum Universitas Indonesia, 2003, hal. 293.

${ }^{17}$ Suyud Margono, Hukum Perlindungan Hak Cipta, Jakarta : CV. Novindo Pustaka Mandiri, 2003, hal. 28.
}

peroleh atau dirasakan dari hasil jerih payah pencipta tadi semakin besar, maka semakin besar pula nilai yang dihasilkan tadi. Karenanya kegiatan memperbanyak dan atau mengumumkan ciptaan atau memberi izin kepada pihak lain untuk ikut memperbanyak dan/atau mengumumkan ciptaan tersebut, merupakan tindakan berdasarkan pertimbangan komersial atau ekonomi. Artinya, kegiatan memperbanyak ataupun bentuk eksploitasi karya cipta lainnya, juga merupakan hak dari pencipta ${ }^{18)}$.

CJT. Simorangkir ${ }^{19)}$ mengemukakan pengertian hak khusus tersebut adalah berarti tidak ada orang atau badan lain yang dapat melakukan hak cipta itu, misalnya untuk mengumumkan atau memperbanyaknya, kecuali dengan izin pencipta. Izin pencipta agar supaya orang atau badan lain boleh melakukan hak cipta itu, dapat berupa atau melalui: a). pewarisan; b). hibah; c). wasiat; d). dijadikan milik negara; e). perjanjian dengan akta.

Sementara itu, H. OK. Saidin ${ }^{20)}$ mengemukakan bahwa "perkataan "tidak ada pihak lain" yang terdapat dalam Pasal 2 UUHC mempunyai pengertian yang sama dengan hak tunggal yang menunjukkan bahwa pencipta saja yang boleh mendapatkan hak semacam itu. Inilah yang disebut hak yang bersifat eksklusif. Eksklusif berarti khusus, spesifikasi, unik. Keunikannya itu, sesuai dengan sifat dan cara melahirkan hak tersebut.

Sebagai konsekwensi dari pengertian hak cipta sebagai suatu hak yang eksklusif, maka setiap orang/ badan usaha yang menggunakan karya cipta lagu dan/atau untuk suatu kegiatan komersil dan atau kepentingan yang berkaitan dengan kegiatan komersil seperti halnya hotel, restaurant, pub, karaoke, dan sebagainya, harus meminta izin terlebih dahulu kepada penciptanya dan atau kepada pemegang hak ciptanya yang oleh pencipta diberi kuasa untuk itu. Dengan kata lain, untuk memanfaatkan hak ekonomi pencipta tersebut, harus minta izin dari pencipta atau pemegang hak cipta yang sah.

Melalui Pasal 9 ayat (2) UUHC dinyatakan bahwa setiap orang yang melaksanakan hak ekonomi sebagaimana dimaksud pada ayat (1) wajib mencapatkan

\footnotetext{
${ }^{18}$ Loc.cit.

${ }^{19}$ JCT. Simorangkir, Undang Undang Hak Cipta 1982, Jakarta : Djambatan, 1982, hal. 123

${ }^{20}$ H. OK. Saidin, Aspek Hukum Hak Kekayaan Intelektual, Jakarta : Raja Grafindo Persada, 2003, hal. 59.
} 
izin pencipta atau pemegang hak cipta. Selanjutnya dalam ayat (3) dijelaskan bahwa setiap orang yang tanpa izin pencipta atau pemegang hak cipta dilarang melakukan penggandaan dan/atau penggunaan secara komersil ciptaan ${ }^{21}$.

Dalam pengertian "mengumumkan atau memperbanyak", termasuk kegiatan menerjemahkan, mengadaptasi, mengaransemen, mengalihwujudkan, menjual, menyewakan, meminjamkan, mengimpor, memamerkan, mempertunjukkan kepada publik, menyiarkan, merekam dan mengkomunikasikan ciptaan kepada publik melalui sarana apapun.

Permasalahan selanjutnya adalah siapakah yang dimaksud dengan "setiap orang" atau "pihak lain" dalam Pasal 9 UUHC yang oleh undang-undang dilarang mengambil manfaat dari karya cipta musik dan lagu tersebut tanpa seizin dari pencipta dan atau pemegang hak ciptanya. Pihak lain yang dimaksud adalah mereka yang menggunakan karya cipta musik untuk suatu kegiatan komersil dan atau kepentingan yang berkaitan dengan kegiatan komersil, seperti halnya hotel, rumah sakit, mal, pertokoan, retail business, salon, spa \& fitness, restoran, pub dan café, karaoke dan discotheque, transportasi, terminal, digital transmission, cinema, broadcaster, one off event, tiket selling background music, dan sebagainya.

Pengguna (user) tersebut dapat dikategorikan menjadi: 1). featuring music, yaitu kegiatan usaha tersebut tidak akan berjalan tanpa menggunakan lagu atau musik, seperti, tempat hiburan, karaoke, pub/ night club, konser musik dan sebagainya; 2). Background music, yaitu suatu tempat usaha dimana musik memberi nilai tambah bagi kegiatan usahanya tersebut, yaitu demi kenyamana pengunjung, seperti café, restorant, hotel dan sebagainya; 3). Entertainment music, yaitu suatu kegiatan usaha yang tidak dapat berjalan dengan baik tanpa menggunakan musik, seperti stasiun televisi, statisun radio, dan sebagainya. Usaha-usaha seperti dikemukakan diatas, sudah barang tentu baik secara langsung maupun secara tidak langsung telah mendapatkan manfaat ekonomis dari penggunaan karya cipta musik dan lagu tersebut dan

\footnotetext{
${ }^{21}$ Pasal 9 ayat (1) UUHC menetapkan bahwa pencipta atau pemegang hak cipta sebagaimana dimaksud dalam Pasal 8 memiliki hak ekonomi untuk melakukan : a). penerbitan ciptaan; b). penggandaan ciptaan; c). penerjemahan ciptaan; d) pengadaptasian, pengaransemenan atau pentransformasian ciptaan; e). pendistribusian ciptaan atau salinannya; f). pertunjukan ciptaan; g). pengumuman ciptaan; h). komunikasi ciptaan, dan; i). penyewaan ciptaan.
}

karenanya mereka wajib meminta izin terlebih dahulu kepada penciptanya serta melakukan pembayaran royalty sebagai kewajiban hukumnya.

Pemberian izin dalam penggunaan karya cipta musik dan lagu oleh para pengguna (user) sebagaimana diuraikan di atas dilakukan dengan perjanjian lisensi. Lisensi itu sendiri adalah izin yang diberikan oleh pemegang hak cipta (musik) kepada pihak lain untuk melaksanakan hak ekonomi atas ciptaanya syarat tertentu. Lisensi pengumuman musik diberikan berdasarkan surat perjanjian lisensi disertai kewajiban pembayaran royalty kepada pemegang hak cipta. Royalty adalah bentuk pembayaran yang dilakukan kepada pemegang hak cipta (musik) karena tidak dapat memanfaatkan sendiri kepemilikannya. Jumlah royalty yang wajib dibayar kepada pemegang hak cipta musik oleh penerima lisensi sesuai undang-undang ditetapkan berdasarkan kelaziman dalam praktik yang berlaku dengan memenuhi unsur keadilan.

\section{AKIBAT HUKUM PENGGUNAAN KARYA CIPTA MUSIK DAN LAGU TANPA IZIN}

Sebagaimana diuraikan di atas, bahwa konsekwensi hak cipta (karya cipta musik dan lagu) sebagai suatu hak yang eksklusif adalah dilarangnya pihak lain dalam memanfaatkan hak ekonomi dari karya cipta musik dan lagu tersebut tanpa izin dari pencipta atau pemegang hak cipta yang sah. Terhadap setiap pelanggaran hak cipta berupa ketiadaan izin tersebut diatas, oleh UUHC telah memberikan perlindungan kepada pencipta berupa gugatan gan- ti rugi secara perdata serta adanya hak negara untuk melakukan penuntutan secara pidana sesuai Pasal 113 UUHC, yang selengkapnya adalah sebagai berikut:

1) Setiap orang yang dengan tanpa hak melakukan pelanggaran hak ekonomi sebagaimana dimaksud dalam Pasal 9 ayat (1) huruf (i) untuk penggunaan sarana komersil dipidana dengan pidana penjara paling lama 1 (satu) tahun dan/atau denda paling banyak Rp. 100.000.000,- (seratus juta rupiah).

2) Setiap orang yang dengan tanpa hak dan/atau tanpa izin pencipta atau pemegang hak cipta melakukan pelanggaran hak ekonomi sebagaimana dimaksud dalam Pasal 9 ayat (1) huruf c, huruf d, huruf $f$ dan/atau huruf $h$ untuk penggunaan sarana komersil dipidana dengan pidana penjara paling lama 3 (tiga) tahun dan/atau denda paling banyak Rp. 500.000.000,- (lima ratus juta rupiah). 
3) Setiap orang yang dengan tanpa hak dan/atau tanpa izin pencipta atau pemegang hak cipta melakukan pelanggaran hak ekonomi sebagaimana dimaksud dalam Pasal 9 ayat (1) huruf a, huruf b, huruf e dan/atau huruf g untuk penggunaan sarana komersil dipidana dengan pidana penjara paling lama 4 (empat) tahun dan/atau denda paling banyak Rp. 1.000.000.000,- (satu milyar rupiah).

4) Setiap orang yang memenuhi unsur sebagaimana dimaksud pada ayat (3) yang dilakukan dalam bentuk pembajakan, dipidana dengan pidana penjara paling lama 10 (sepuluh) tahun dan/atau denda paling banyak Rp. 4.000.000.000,- (empat milyard rupiah)

Sesuai Pasal 120 UUHC tindak pidana pelanggaran hak cipta adalah merupakan delik aduan.

Atas pelanggaran hak eksklusif pencipta musik, undang-undang memberikan perlindungan hukum bagi pencipta atau pemegang hak ciptanya untuk mengajukan gugatan ganti kerugian melaluipengadilan niaga. Pemegang hak cipta dapat minta ke pengadilan niaga untuk menarik dari peredaran dan menyita serta menyimpan sebagai alat bukti yang berkaitan dengan pelanggaran hak ciptanya. Termasuk menghentikan pelanggaran guna mencegah kerugian yang lebih besar.

Dapat dilihat, betapa UUHC memberikan perlindungan terhadap pemegang hak cipta musik secara privat melalui penetapan pengadilan niaga sebagai lembaga yang berwenang selain arbitrase dan alternatif penyelesaian sengketa untuk memutus sengketa atau pelanggaran hak cipta dengan berbagai hak sebagaimana diuraikan diatas serta penetapan jangka waktu penyelesaian perkaranya. Dengan ditetapkannya pengadilan niaga sebagai lembaga yang berwenang untuk memutus sengketa hak cipta, maka asas peradilan cepat dan kepastian hukum dapat segera diwujudkan, mengingat ditetapkannya batas waktu untuk menyelesaikan dan memutus tuntutan ganti kerugian tersebut selama 90 (sembilan puluh) hari sejak gugatan didaftarkan dan dapat diperpanjang paling lama 30 (tiga puluh) hari atas persetujuan mahkamah agung. Terhadap putusan pengadilan niaga tersebut hanya tersedia upaya hukum kasasi yang dalam jangka waktu 90 (sembilan puluh) hari setelah permohonan kasasi diterima, mahkamah agung harus memberikan putusan atas permohonan kasasi tersebut.

\section{KESIMPULAN}

1. Konsekuensi hak cipta (musik dan lagu) sebagai suatu hak yang eksklusif (khusus) adalah bahwa setiap orang yang ingin memanfaatkan hak ekonomi pencipta atas ciptaannya diwajibkan menurut hukum untuk meminta izin kepada pencipta atau pemegang hak ciptanya yang sah.

2. Akibat hukum penggunaan karya cipta (musik dan lagu) tnpa izin dari pencipta atau pemegang hak ciptanya yang sah adalah gugatan ganti kerugian secara perdata melalui pengadilan niaga dan tuntutan pidana berupa tindak pidana pelanggaran hak cipta yang menurut undang undang merupakan suatu jenis tindak pidana aduan.

\section{SARAN}

1. Perlu sosialisasi lebih lanjut dari ketentuan peraturan perundang-undangan bidang hak cipta, khususnya Undang Undang RI No. 28 Tahun 2014 tentang Hak Cipta serta sejumlah aturan organik lainnya, sehingga masyarakat khususnya pengguga atau pelaku usaha dapat memahaminya secara komprehensif.

2. Mengingat maraknya pelanggaran hak cipta musik yang terjadi dalam masyarakat, terutama dalam bidang performing right, sudah saatnya para aparat penegak hukum mempunyai komitmen yang tegas dalam penegakan hukumnya (enforcement law) yang diimbangi dengan sosialisasiatas ketentuan-ketentuan yang terdapat dalam peraturan perundang-undangan hak cipta. 
Jurnal Hukum tô-râ, Vol. 1 No. 2, Agustus 2015

\section{DAFTAR PUSTAKA}

\section{Buku:}

Adisumarto Harsono, Hak Milik Intelektual Khususnya Hak Cipta, Jakarta: Akademika Pressindo, 1990.

Departemen Pendidikan Nasional, Kamus Besar Bahasa Indonesia, Jakarta: Balai Pustaka, 2005.

Eddy Damian, Hukum hak Cipta Menurut Konvensi Internasional, Undang Undang Hak Cipta 1987 dan Perlindungan Terhadap Buku Serta Perjanjian Penerbitannya, Bandung: Alumni, 1999.

Ensiklopedia Indonesia, buku 4, Jakarta: PT. Ichtiar Baru-van Hove, tanpa tahun..

H. OK. Saidin, Aspek Hukum Hak Kekayaan Intelektual, Jakarta: Raja Graffindo Persada, 2003.

Hendra Tanu Hendra, Hak Cipta Musik atau lagu, Jakarta: Fakultas Hukum Pascasarjana Universitas Indonesia, 2003.

Hulman Panjaitan dan Wetmen Sinaga, Performing Right Hak Cipta Atas Karya Musik dan Lagu serta Aspek Hukumnya, Jakarta: Indohill-co, 2010.

J.C.T. Simorangkir, Undang-Undang Hak Cipta 1982, Jakarta: Pustaka Sinar Harapan, 1984.

M. Soeharto, Kamus Musik, Jakarta: PT. Gramedia Widiasarana. 1992.

Muhamad Djumhana dan R. Djubaedillah, Hak Milik Intelektual, Sejarah, Teori dan Praktiknya di Indonesia,

Bandung: Citra Aditya Bakti, 1997.

Otto Hasibuan, Hak Cipta Di Indonesia, Tijauan Khusus Hak Cipta Lagu, Neightboring Rights dan Collecting Society, Bandung: PT. Alumni, 2008.

Rooseno Hardjowidigdo, Perjanjian Lisensi Hak Cipta Musik Dalam Pembuatan Rekaman, Jakarta: Perum Percetakan Negara RI.

Sanusi Bintang, Hukum Hak Cipta, Bandung: Citra Aditya Bhakti, 1998.

Suyud Margono, Hukum Perlindungan Hak Cipta, Jakarta: CV. Novindo Pustaka Mandiri, 2003. dan Longginus Hadi, Pembaharuan Perlindungan Hukum Merek, Jakarta: CV. Novindo Pustaka Mandiri, 2002.

\section{Undang-Undang:}

Undang-Undang Republik Indonesia Nomor 28 Tahun 2014 tentang Hak Cipta.

Keputusan Menteri Hukum dan Perundang-undangan Republik Indonesia Nomor Nomor M.03.PR.07.10 tahun 2000 


\section{Majalah, Artikel, Surat Kabar:}

International Intellectual Property Alliance, 2002 Special Report, Indonesia Executive Summary, 2002. Harian Kompas, 9 Agustus 1999.

Harian Suara Pembaharuan, 3 Agustus 2009. Majalah Potret, Nopember-Desember 2009. 